\title{
Thyroid hormone deiodination in the domestic cat
}

\author{
D J Foster ${ }^{1}$, K L Thoday ${ }^{1}$ and G J Beckett ${ }^{2}$
}

\author{
${ }^{1}$ The University of Edinburgh, Department of Veterinary Clinical Studies, The Hospital for Small \\ Animals, Easter Bush, Roslin, Midlothian EH25 9RG, UK \\ ${ }^{2}$ The University of Edinburgh, Department of Clinical Biochemistry, Royal Infirmary of Edinburgh, \\ Lauriston Place, Edinburgh EH3 9YW, UK
}

(Requests for offprints should be addressed to G J Beckett)

\begin{abstract}
We have investigated thyroid hormone deiodination in the liver, kidney and thyroid of the domestic cat. Affinity labelling with ${ }^{125} \mathrm{I}$-bromoacetyl reverse $\mathrm{T}_{3}$ $\left({ }^{125} \mathrm{I}-\mathrm{BrAc}-\mathrm{r} \mathrm{T}_{3}\right)$ demonstrated that liver and kidney, but not the thyroid, express type I iodothyronine deiodinase (IDI), results that were confirmed by measuring the activity of the IDI using ${ }^{125} \mathrm{I}-\mathrm{r}^{\mathrm{T}} \mathrm{T}_{3}$ and $\mathrm{T}_{4}$ as substrate. Feline hepatic and renal IDI metabolised $\mathrm{rT}_{3}$ at approximately $0 \cdot 2 \%$ of the rate of rat hepatic IDI under identical assay conditions.
\end{abstract}

The $K_{\mathrm{m}}$ of the feline enzyme was at least 500 -fold greater than that of rat IDI. However, feline and rat hepatic IDI metabolised $\mathrm{T}_{4}$ at a similar rate and had similar $K_{\mathrm{m}}$ values $(1.35 \mu \mathrm{M}$ and $2.25 \mu \mathrm{M}$, respectively). This study demonstrates that cats and rats express IDI in the liver and kidney in similar concentrations; however, the feline enzyme appears unable to utilise $\mathrm{rT}_{3}$ as a substrate under physiological conditions.

Fournal of Molecular Endocrinology (2000) 24, 119-126

\section{INTRODUCTION}

The thyroid gland provides the sole source of circulating thyroxine $\left(\mathrm{T}_{4}\right)$, which is regarded as a prohormone requiring $5^{\prime}$-deiodination to produce the metabolically active hormone, $3,5,3^{\prime}$ triiodothyronine $\left(\mathrm{T}_{3}\right)$. Conversion of $\mathrm{T}_{4}$ to $\mathrm{T}_{3}$ by 5 -mono-deiodination in a number of tissues, including the liver and kidney, is an important source of plasma $\mathrm{T}_{3}$ (Silva \& Larsen 1986, Kohrle 1994, St Germain 1994). There are clear tissue differences in the source of $\mathrm{T}_{3}$ that is bound to nuclear $\mathrm{T}_{3}$ receptors: in brain, approximately $80 \%$ of $\mathrm{T}_{3}$ residing on the nuclear receptors appears to arise from deiodination of $\mathrm{T}_{4}$ within the tissue whereas, in contrast, in the kidney, approximately $90 \%$ of nuclear $\mathrm{T}_{3}$ arises from plasma $\mathrm{T}_{3}$ (Silva \& Larsen 1986). Thyroxine may also undergo 5 -deiodination in many tissues to yield the metabolically inactive molecule, $3,3^{\prime}, 5^{\prime}$ triiodothyronine (reverse $\mathrm{T}_{3}: \mathrm{rT}_{3}$ ). Deiodination of thyroid hormones thus plays a crucial role in the regulation of the $\mathrm{T}_{3}$ supply to both tissue and blood (Kohrle 1994, St Germain 1994).

Deiodination of thyroxine and other iodothyronines is catalysed by the family of iodothyronine deiodinases (ID), and current evidence suggests that these enzymes provide an autoregulatory role in many tissues to maintain intracellular $T_{3}$ in response to altered thyroidal secretion of thyroid hormones (St Germain \& Croteau 1989, Kohrle 1994). In addition, the deiodinases appear to be of critical importance during development, ensuring there is a regulated and co-ordinated exposure of specific tissues to thyroid hormones (Mitchell et al. 1998, Richard et al. 1998). Three selenoenzymes are involved in the deiodination of thyroid hormones, namely iodothyronine deiodinase types I, II and III (IDI, IDII, IDIII). IDI is the major isoenzyme found in liver and kidney and this enzyme appears to provide the major proportion of $\mathrm{T}_{3}$ found in plasma. IDI is also expressed in high concentrations in the thyroid of some species, including humans, dogs and rodents, but many animal species, including goat, cattle and sheep, fail to express the enzyme, or at least express it at very low levels within the gland (Beckett et al. 1993). IDI can catalyse both $5^{\prime}$ - and 5-mono-deiodination to produce $\mathrm{T}_{3}$ and $\mathrm{rT}_{3}$, respectively, from $\mathrm{T}_{4}(\mathrm{St}$ Germain \& Croteau 1989, Beckett \& Arthur 1994). In rats and humans, IDI appears to show a substrate preference for $\mathrm{r}_{3}$, although it can readily act on $\mathrm{T}_{4}$ (Visser et al. 1988).

IDII is not expressed by liver or kidney, but the enzyme appears to provide an important intracellular source of $\mathrm{T}_{3}$ in many other tissues, 
including the central nervous system, pituitary, thyroid and brown adipose tissue of some species including the rat (St Germain \& Croteau 1989, Leonard \& Kohrle 1996). IDII catalyses only 5'deiodination and has $\mathrm{T}_{4}$ as its preferred substrate. IDIII performs only 5 -deiodination and acts on $\mathrm{T}_{3}$ in preference to $\mathrm{T}_{4}$ (Leonard \& Kohrle 1996).

A number of methods have been used to assay IDI expression and activity. Expression of the enzyme is usually assessed with an affinity labelling technique using ${ }^{125}$ I-bromoacetyl derivatives of $\mathrm{rT}_{3}, \mathrm{~T}_{3}$ or $\mathrm{T}_{4}$ (Kohrle et al. 1990, Schoenmakers et al. 1992). Activity is measured by assessing the ability of IDI and IDII to metabolise $\mathrm{T}_{4}$ or $\mathrm{rT}_{3}$ in the presence of an active thiol agent such as dithiothreitol (DTT) (Leonard \& Rosenberg 1978, Visser \& Overmeeren-Kaptein 1981, Moreno et al. 1994). IDI and IDII show very different sensitivities to inhibition by the addition of propylthiouracil (PTU) and gold-thioglucose (GTG). IDI activity with $\mathrm{rT}_{3}$ or $\mathrm{T}_{4}$ as substrate is readily inhibited by both these agents (Santini et al. 1992, Beckett \& Arthur 1994), whereas IDII is relatively resistant to inhibition by PTU or GTG (St Germain 1994). These inhibitors are thus often used to indicate which isoenzyme is expressed by tissues.

Previous studies have suggested that IDI has similar properties in most species investigated. Apart from canine IDI, the main differences reported have been confined to small variations in molecular mass (Schoenmakers et al. 1992), differences in turnover number of approximately 10 -fold between species (Santini et al. 1992, Schoenmakers et al. 1992) and differences in sensitivity to inhibition by GTG (Santini et al. 1992). However, there have been reported clear species differences concerning the degree of expression of IDI by the thyroid (Beckett et al. 1993, Beech et al. 1993).

Feline hyperthyroidism, resulting almost exclusively from hyperfunctional adenomas, is the most common endocrine disease in the cat (Thoday et al. 1984). Little is known regarding the pathogenesis of the disease and, at a fundamental level, very little is known regarding thyroid hormone metabolism, and in particular, deiodination, in this animal species. The present study was undertaken to identify the characteristics of thyroid hormone deiodination in the thyroid, liver and kidney of the domestic cat.

\section{MATERIALS AND METHODS}

\section{Animal tissues}

Tissues (liver, kidney and thyroid) were obtained from five cats immediately after euthanasia by a lethal dose of intravenous barbiturate, placed in liquid nitrogen and stored at $-80{ }^{\circ} \mathrm{C}$ until assays were carried out. All cats were of mixed breeding and between the ages of 2 and 16 years. They were subject to euthanasia because of diseases that were not affecting the organs studied (two cats had upper respiratory tract disease; three had gastrointestinal disease). Rat tissues were obtained and stored in a similar manner.

\section{Preparation of tissue homogenates, cytosols and microsomal fractions}

Portions of tissues were homogenised in $100 \mathrm{mM}$ $\mathrm{KH}_{2} \mathrm{PO}_{4} / 1 \mathrm{mM}$ EDTA buffer $\mathrm{pH} 7 \cdot 4$ (IDI assay buffer), at $20 \% \mathrm{w} / \mathrm{v}$, and centrifuged at $1500 \mathrm{~g}$ for $10 \mathrm{~min}$ at $5{ }^{\circ} \mathrm{C}$. The supernatant was removed and used immediately for the assay of IDI activity. A microsomal fraction of tissue was also prepared by collecting a portion of the post- $1500 \mathrm{~g}$ supernatant and centrifuging it at $12000 \boldsymbol{g}$ for $20 \mathrm{~min}$, the resulting supernatant then being centrifuged further at $105000 \mathrm{~g}$ for $60 \mathrm{~min}$ at $5^{\circ} \mathrm{C}$. The microsomal pellet was resuspended and washed once in IDI assay buffer and recentrifuged at $105000 \mathrm{~g}$. The washed microsomal pellet was resuspended in IDI assay buffer to a protein concentration of $1 \mathrm{mg} / \mathrm{ml}$.

\section{Protein determinations}

Protein concentrations were determined by the method described by Bradford (1976) using bovine serum albumin (BSA) as standard.

\section{Assay of deiodinase activity using ${ }^{125} \mathrm{I}-\mathrm{r} \mathrm{T}_{3}$ as substrate}

The assay procedure was based on that of Sawada et al. (1986). Before use, ${ }^{125} \mathrm{I}-\mathrm{r} T_{3}$ (NEN biochemicals, Hounslow, Middx, UK; $9250 \mathrm{KBq} / 1 \cdot 25 \mathrm{ml}$, $27 \cdot 8-46 \cdot 3 \mathrm{MBq} / \mu \mathrm{g}$ ) was purified as follows. Free iodine-125 was removed by passing the tracer down a $2 \mathrm{ml}$ Sephadex G25 column in IDI assay buffer. The column was washed with $20 \mathrm{ml}$ IDI assay buffer to remove contaminating iodine-125 and the ${ }^{125} \mathrm{I}_{-} \mathrm{rT}_{3}$ was eluted with a $1 \%(\mathrm{w} / \mathrm{v})$ solution of BSA prepared in IDI assay buffer.

Tissue homogenates $(200 \mu \mathrm{l} ; n=5$, post-1500 $\boldsymbol{g}$ centrifugation) in duplicate were incubated with $100 \mu \mathrm{l}$ purified ${ }^{125} \mathrm{I}_{-} \mathrm{rT}_{3}$ at a final activity of $0.5 \mu \mathrm{Ci} / \mathrm{ml}$ in the presence of $20 \mathrm{mM}$ DTT and a final $\mathrm{rT}_{3}$ concentration of $6 \mathrm{nM}$. The final volume of the incubation mix was $900 \mu \mathrm{l}$. For kinetic experiments, $\mathrm{rT}_{3}$ was added in concentrations spanning the range $5 \mathrm{nM}$ to $500 \mu \mathrm{M}$. Samples were incubated at $37^{\circ} \mathrm{C}$ for the times indicated in the 
results section, and the reaction was stopped by the addition of $0.4 \mathrm{ml}$ human sera, followed by $0.4 \mathrm{ml}$ $40 \%$ trichloroacetic acid. After centrifugation at $1500 \mathrm{~g}$ for $10 \mathrm{~min}, 0 \cdot 8 \mathrm{ml}$ supernatant were removed and counted together with tubes containing the remaining supernatant and pellet. The percentage of iodine-125 released was calculated and used to determine the mass of $\mathrm{rT}_{3}$ that had been metabolised.

\section{Effects of PTU and GTG on deiodinase activity}

The inhibition of IDI in activity assays was investigated by the addition of $1 \mathrm{mM}$ PTU or $12 \mathrm{nM}$ GTG (final concentration) as described previously (Berry et al. 1991, Santini et al. 1992).

\section{Assay of IDI activity in tissue homogenates using $\mathrm{T}_{\mathbf{4}}$ as substrate}

This was performed as described previously (Beckett et al. 1987). A solution of $\mathrm{T}_{4}(56 \mu \mathrm{M})$ was prepared in $0.25 \mathrm{M}$ sucrose $/ 0.05 \mathrm{M}$ Tris $/ 1 \mathrm{mM}$ EDTA buffer pH $7 \cdot 4$ containing 3\% BSA to ensure that the $\mathrm{T}_{4}$ remained in solution. Tissue homogenates $(2 \mathrm{ml})$ prepared as described above were then preincubated for $10 \mathrm{~min}$ at $37^{\circ} \mathrm{C}$ and $\mathrm{T}_{4}$ (final concentration $5 \cdot 1 \mu \mathrm{M} ; 200 \mu \mathrm{l})$ and DTT $(20 \mathrm{mM}$ final concentration) were added to start the reaction. At designated time points, $200 \mu \mathrm{l}$ samples were removed in duplicate into $400 \mu \mathrm{l}$ ethanol and centrifuged at $1500 \mathrm{~g}$ for $5 \mathrm{~min}$. The concentration of $\mathrm{T}_{3}$ was then determined by immunoassay using a Vitros Eci immunoassay analyser (Ortho Clinical Diagnostics, Rochester, NY, USA).

\section{Affinity labelling of IDI in microsomal liver fraction}

${ }^{125} \mathrm{I}-\mathrm{N}$-bromoacetyl-r $\mathrm{T}_{3}\left({ }^{125} \mathrm{I}-\mathrm{BrAc}-\mathrm{r} \mathrm{T}_{3}\right)$ was prepared as described previously (Schoenmakers et al. 1992). Two hundred microlitres ${ }^{125} \mathrm{I}_{-} \mathrm{rT}_{3}$ were evaporated to dryness under a stream of dry nitrogen and $20 \mu \mathrm{l} 1.5 \mathrm{mg} / \mathrm{ml}$ bromoacetic acid $N$-hydroxysuccinamide ester in dimethylformamide were added to the dried tracer. To this, $5 \mu 110 \%$ $(\mathrm{v} / \mathrm{v})$ triethylamine in dimethylformamide was subsequently added and the mixture left at room temperature for $50 \mathrm{~min}$. The iodinated affinity label was then purified by passing it through an LH20 Sephadex column $(2 \mathrm{ml})$ equilibrated with $0 \cdot 1 \mathrm{M}$ $\mathrm{HCl}$. The label was eluted with $95 \%$ ethanol and stored at $-20{ }^{\circ} \mathrm{C}$ until used (within 7 days).

Microsomal fractions isolated from tissues as described above were diluted to a final concen- tration of $1 \mathrm{mg} / \mathrm{ml}$ protein in $50 \mathrm{mM}$ Tris $\mathrm{HCl}$, $3 \mathrm{mM}$ EDTA, $3 \mathrm{mM}$ DTT. Microsomes $(50 \mu \mathrm{l}$; $50 \mu \mathrm{g}$ protein) were then added to $0.6 \mu \mathrm{Ci}{ }^{125} \mathrm{I}$ $\mathrm{BrAc}-\mathrm{rT}_{3}$ affinity label, which had been evaporated to dryness under dry nitrogen. The reaction was allowed to proceed for $15 \mathrm{~min}$.

For experiments designed to study the effects of PTU and GTG on IDI affinity labelling, either $1 \mathrm{mM}$ PTU or $40 \mathrm{nM}$ GTG (Santini et al. 1992) were added to each test before addition of the affinity label. The effects of $\mathrm{rT}_{3}$ and $\mathrm{P}$ TU on affinity labelling were also studied with the addition of $6 \mathrm{nM} \mathrm{rT}$ together with $1 \mathrm{mM}$ PTU. Samples were then diluted $2: 1$ with 'boiling mix' consisting of SDS $(35 \mathrm{mM})$, glycerol $(1.4 \mathrm{mM})$, 2-mercaptoethanol $(0 \cdot 3 \mathrm{mM})$ and bromophenol blue $(15 \mathrm{mM})$, and then heated for $10 \mathrm{~min}$ at $90{ }^{\circ} \mathrm{C}$.

After affinity labelling, samples were subjected to SDS polyacrylamide gel electrophoresis using a $12 \%$ $(\mathrm{w} / \mathrm{v})$ gel, and the ${ }^{125} \mathrm{I}$-labelled proteins visualised using autoradiography.

\section{Determination of deiodination kinetics of $\mathbf{r} \mathrm{T}_{3}$ and $\mathrm{T}_{\mathbf{4}}$ for IDI}

$K_{\mathrm{m}}$ and $V_{\text {max }}$ were determined by construction of Lineweaver-Burke plots. Final concentrations of $\mathrm{rT}_{3}$ and $\mathrm{T}_{4}$ ranged from $100 \mathrm{nM}$ to $50 \mu \mathrm{M}$ and $5 \mathrm{nM}$ to $5 \cdot 1 \mu \mathrm{M}$ respectively.

\section{Serum $\mathbf{r T}_{3}$ concentrations}

A commercial rT ${ }_{3}$ RIA kit (Biostat Diagnostics, Stockport, Cheshire, UK) was used to measure the $\mathrm{rT}_{3}$ concentrations in serum from 10 euthyroid cats and 10 euthyroid rats. The Mann-Whitney $U$ test was used to test for significant difference between the $\mathrm{rT}_{3}$ concentrations in cats and rats.

\section{RESULTS}

\section{IDI activity in tissue homogenates and microsomal fractions using $\mathrm{rT}_{3}$ and $\mathrm{T}_{4}$ as substrates}

\section{${ }^{125} I-r T_{3}$ as substrate}

When ${ }^{125} \mathrm{I}_{-} \mathrm{rT}_{3}(6 \mathrm{nM})$ was used as substrate, feline liver and kidney homogenates showed approximately $0 \cdot 2 \%$ of the deiodinase activity found in rat liver (Table 1). Because of the low deiodinase activity found in feline liver and kidney, it was necessary to use an incubation period of between 4 and $24 \mathrm{~h}$ whereas, using rat liver, an incubation period of only 5 min with a $1: 10$ dilution of homogenate was required. In each case, 
TABLE 1. IDI activity in tissue homogenates $(n=5)$ with $\mathrm{rT}_{3}(6 \mathrm{nM})$ and $\mathrm{T}_{4}$ $(5 \cdot 1 \mu \mathrm{M})$ as substrates

Rat liver

Rat liver plus PTU (1 mM)

Rat liver plus GTG (12 nM)

Cat liver

Cat liver plus PTU $(1 \mathrm{mM})$

Cat liver plus GTG (12 nM)

Cat kidney

Cat thyroid (2 euthyroid, 3 thyrotoxic)

ND, not detectable.

\begin{tabular}{|c|c|}
\hline \multicolumn{2}{|l|}{ Deiodinase activity } \\
\hline $\begin{array}{l}\mathrm{rT}_{3} \\
(\mathrm{fmol} / \mathrm{mg} \text { per } \mathrm{min})\end{array}$ & $\begin{array}{l}\mathrm{T}_{4} \\
(\mathrm{nmol} / \mathrm{mg} \text { per } \min )\end{array}$ \\
\hline $23800 \pm 990$ & $3 \cdot 71 \pm 0 \cdot 49$ \\
\hline ND & $0 \cdot 382 \pm 0 \cdot 003$ \\
\hline ND & $0 \cdot 02 \pm 0 \cdot 03$ \\
\hline $42 \cdot 33 \pm 7 \cdot 16$ & $3 \cdot 61 \pm 0.06$ \\
\hline $0 \cdot 07 \pm 0 \cdot 06$ & $0 \cdot 002 \pm 0 \cdot 01$ \\
\hline $0 \cdot 05 \pm 0 \cdot 04$ & ND \\
\hline $68 \cdot 79 \pm 6 \cdot 26$ & - \\
\hline ND & - \\
\hline
\end{tabular}

homogenates could only be approximated, as it was impossible to obtain $\mathrm{rT}_{3}$ in solution at concentrations greater than $50 \mu \mathrm{M}$. Thus only data points with substrate concentrations well below the $K_{\mathrm{m}}$ of the enzyme could be used. With $\mathrm{T}_{4}$ as substrate, the $K_{\mathrm{m}}$ and $V_{\max }$ of the enzymes in rat and feline liver homogenates were very similar.

\section{${ }^{125}$ I-BrAc-r $\mathrm{T}_{3}$ affinity labelling}

In rat liver microsomes $(n=4)$, affinity labelling with ${ }^{125} \mathrm{I}_{-\mathrm{BrAc}-\mathrm{rT}}$ demonstrated an ${ }^{125} \mathrm{I}$-labelled band with molecular mass $29 \cdot 1 \pm 0 \cdot 9 \mathrm{kDa}$. This labelled protein has previously been characterised as IDI in this tissue. The labelling of this protein was prevented in the presence of PTU and GTG (Figs 1, 2). Similarly, in feline liver and kidney microsomes, a ${ }^{125}$ I-labelled band was found with molecular mass $26 \cdot 2 \pm 0 \cdot 3 \mathrm{kDa}$ (Fig. 1) and $27 \cdot 2 \pm 0 \cdot 1 \mathrm{kDa}$ (Fig. 2) respectively. As in rat liver, the labelling of this protein was prevented by the addition of PTU and GTG. The affinity-labelled proteins in cat liver and cat kidney showed a labelling intensity similar to that of the $29 \mathrm{kDa}$ labelled protein found in rat liver.

\section{Kinetic studies}

The kinetic data for rat and feline liver homogenates for $\mathrm{r}_{3}$ and $\mathrm{T}_{4}$ are shown in Table 2 . The $K_{\mathrm{m}}$ for rat and cat liver using $\mathrm{rT}_{3}$ as substrate were markedly different, the $K_{\mathrm{m}}$ for cat liver using $\mathrm{rT}_{3}$ as a substrate being at least 500 -fold greater than that for rat liver. The $K_{\mathrm{m}}$ values using $\mathrm{rT}_{3}$ in cat liver

TABLE 2. Kinetic data for rat and feline liver homogenates $(n=3)$, with $\mathrm{rT}_{3}$ or $\mathrm{T}_{4}$ as substrate. Values are medians (range)

\begin{tabular}{|c|c|c|}
\hline & $\mathbf{r} \mathbf{T}_{3}$ & $\mathbf{T}_{4}$ \\
\hline \multicolumn{3}{|l|}{ Rat } \\
\hline$K_{\mathrm{m}}(\mu \mathrm{M})$ & $0 \cdot 20(0 \cdot 16-0 \cdot 40)$ & $2 \cdot 25(0 \cdot 54-3 \cdot 06)$ \\
\hline$V_{\max }(\mathrm{pmol} / \mathrm{mg}$ per min $)$ & $100 \cdot 00(12 \cdot 50-100 \cdot 00)$ & $0.625(0 \cdot 18-2 \cdot 50)$ \\
\hline \multicolumn{3}{|l|}{ Cat } \\
\hline$K_{\mathrm{m}}(\mu \mathrm{M})$ & $>100(>100)$ & $1 \cdot 35(0 \cdot 44-4 \cdot 20)$ \\
\hline$V_{\max }(\mathrm{pmol} / \mathrm{mg}$ per $\min )$ & $56 \cdot 20(25 \cdot 00-142 \cdot 80)$ & $0 \cdot 25(0 \cdot 07-0 \cdot 34)$ \\
\hline
\end{tabular}




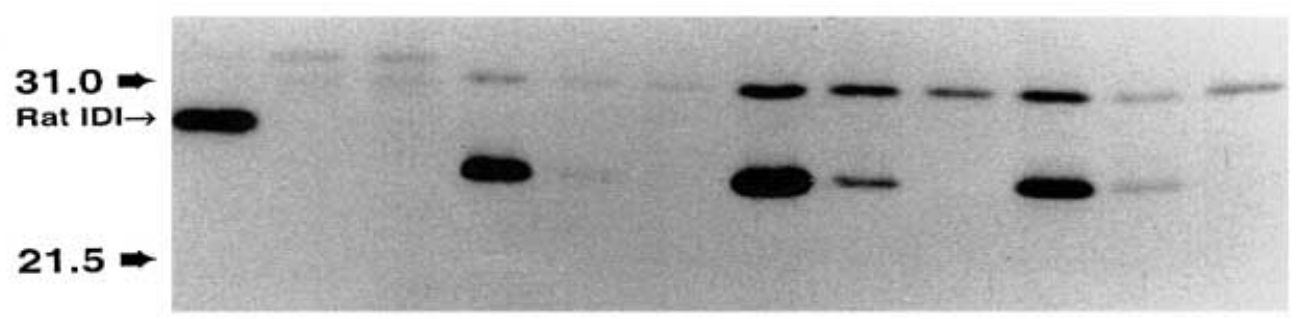

\section{世Feline IDI A}

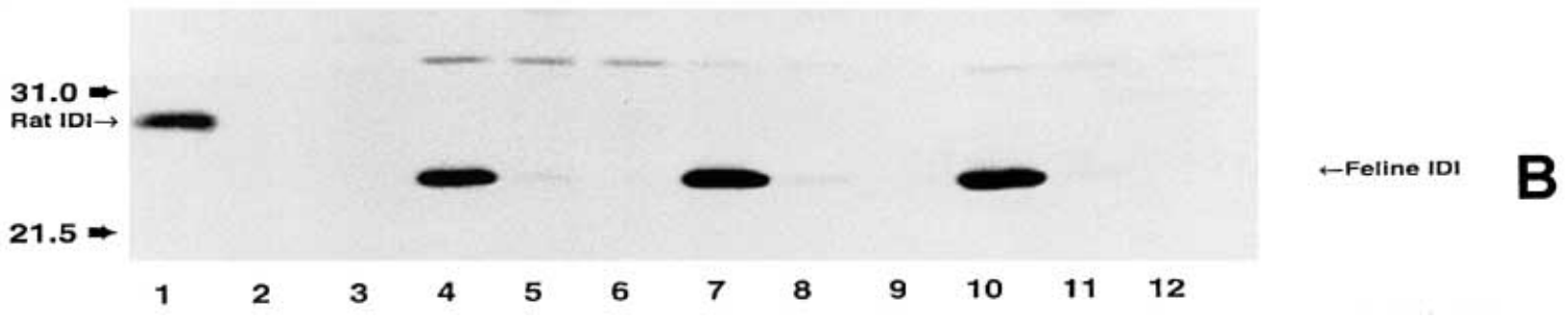

FIGURE 1. Affinity labelling of rat liver and cat liver (A) and kidney (B) microsomes with ${ }^{125} \mathrm{I}_{-} \mathrm{BrAc}-\mathrm{r} \mathrm{T}_{3}$ in the presence of PTU and $\mathrm{rT}_{3}$. Lanes: 1, rat liver microsomes; 2, rat liver microsomes with $1 \mathrm{mM} \mathrm{PTU;} \mathrm{3,} \mathrm{rat} \mathrm{liver}$ microsomes with $1 \mathrm{mM}$ PTU $+6 \mathrm{nM} \mathrm{rT}_{3} ;$ 4, 7, 10, cat liver/kidney microsomes; 5, 8, 11, cat liver/kidney microsomes with $1 \mathrm{mM}$ PTU; 6, 9, 12, cat liver/kidney microsomes with $1 \mathrm{mM}$ PTU+6 nM rT ${ }_{3}$.

\section{Serum $\mathbf{r T}_{3}$ concentration in euthyroid cats}

The mean \pm S.D. serum $\mathrm{r}_{3}$ concentration in cats was $164 \pm 57 \mathrm{pM}$ (range 86-244 pM). The mean serum $\mathrm{rT}_{3}$ concentration in rats was $330 \pm 40 \mathrm{pM}$ (range $267-371 \mathrm{pM})$. The serum $\mathrm{rT}_{3}$ concentration in cats was significantly lower than that in rats $(P=0 \cdot 001)$.

\section{DISCUSSION}

The iodothyronine deiodinases play a crucial role in regulating thyroid hormone metabolism in many tissues. The expression of the selenoenzyme IDI has been studied extensively in humans and rats, and such work has suggested that this enzyme
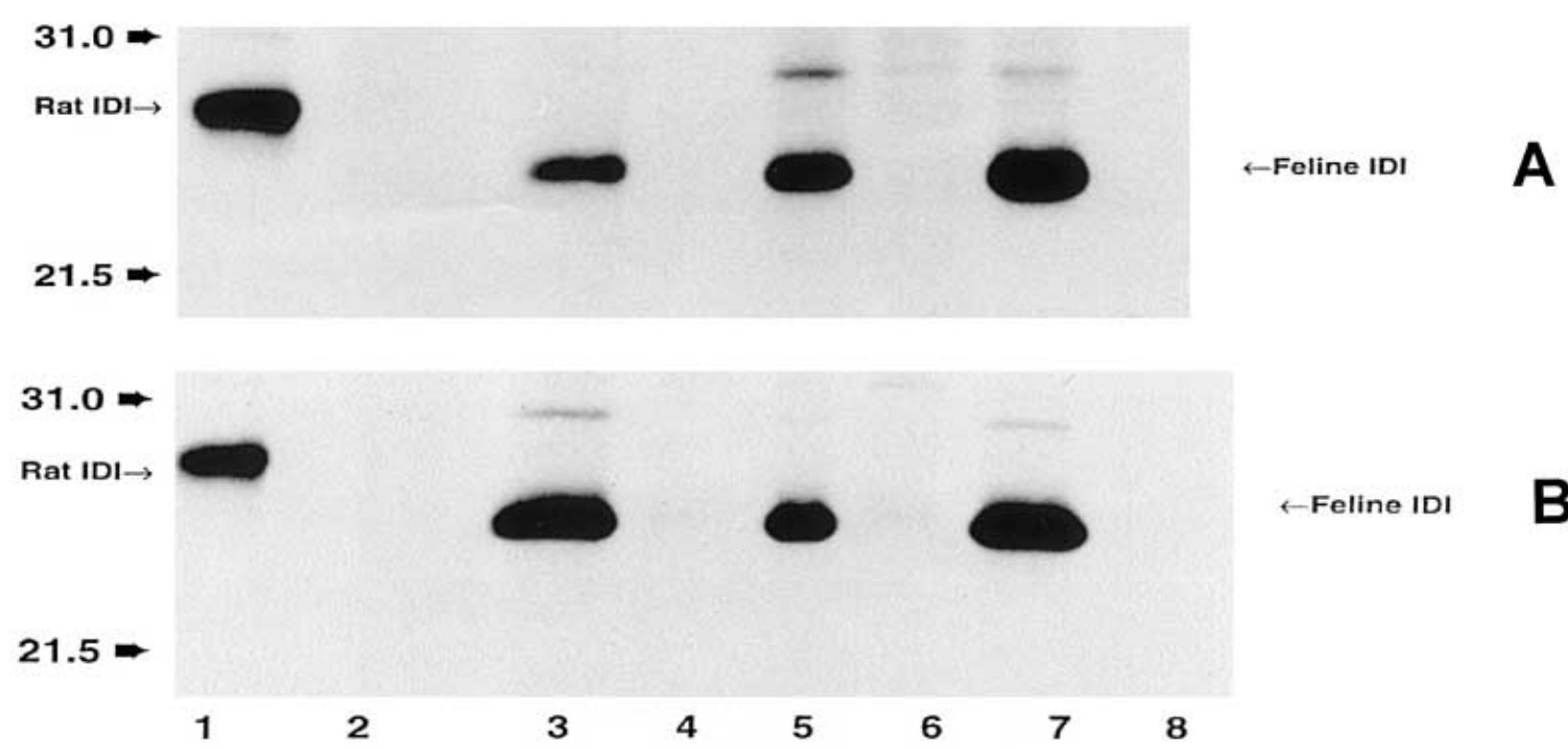

FIGURE 2. Affinity labelling of rat liver and cat liver (A) and kidney (B) microsomes with ${ }^{125} \mathrm{I}-\mathrm{BrAc}-\mathrm{r} \mathrm{T}_{3}$ in the presence of GTG. Lanes: 1, rat liver microsomes; 2, rat liver microsomes with $40 \mathrm{nM} \mathrm{GTG;} \mathrm{3,} \mathrm{5,} \mathrm{7,} \mathrm{cat} \mathrm{liver/kidney}$ microsomes; 4, 6, 8, cat liver microsomes with $40 \mathrm{nM}$ GTG. 
provides a major source of plasma $\mathrm{T}_{3}$. However, the observation that the preferred substrate for IDI in these species is $\mathrm{rT}_{3}$ and not $\mathrm{T}_{4}$ has led some to suggest that a major role of IDI may be to metabolise $\mathrm{rT}_{3}$ (Visser et al. 1988). More limited studies of IDI have been reported in other species, but the use of affinity labelling with ${ }^{125} \mathrm{I}-\mathrm{BrAc}-\mathrm{r} \mathrm{T}_{3}$ has suggested that the hepatic expression of IDI is greatest in the rat and dog, with humans, mice, rabbits, cows, pigs, sheep, goats, chickens and ducks having a similar level of expression (Schoenmakers et al. 1992). Activity measurements of IDI with $\mathrm{rT}_{3}$ as substrate have shown that there are also clear species differences in the turnover number of hepatic IDI. Rats, rabbits and goats have the greatest turnover number, whereas dogs have the lowest, which is approximately 10 times lower than that found in the rat. No studies on feline IDI have been reported.

We have shown that, although certain characteristics of hepatic and renal IDI are similar in the cat and rat, the substrate specificity of the enzyme between these species is clearly different. Affinity labelling of hepatic microsomes using ${ }^{125} \mathrm{I}-\mathrm{BrAc}-$ $\mathrm{rT}_{3}$ demonstrated that the feline enzyme was expressed at levels similar to those found in the rat, although the feline enzyme had a molecular mass that was approximately $3 \mathrm{kDa}$ smaller than that of the rat enzyme. Such modest differences in the molecular mass of IDI have been reported previously between many species (Schoenmakers et al. 1992). The sensitivity of the rat and feline enzyme to PTU and GTG was also similar, in that both these agents prevented affinity labelling of IDI by ${ }^{125} \mathrm{I}-\mathrm{BrAc}-\mathrm{r} \mathrm{T}_{3}$. The feline kidney also expressed levels of IDI similar to those found in feline liver, as assessed by affinity labelling.

When the activity of IDI was compared in rat and feline liver homogenates using $\mathrm{T}_{4}$ as substrate, we found that the relative activities of the enzyme were not significantly different between the species (Table 1). More detailed kinetic analysis showed that the $K_{\mathrm{m}}$ for $\mathrm{T}_{4}$ of the rat enzyme was similar to that of the feline enzyme. The $V_{\max }$ of the enzyme in cat and rat liver was also not significantly different, which was in agreement with the affinity labelling data, which also suggested that similar masses of enzyme were present in each of the tissues.

The use of $\mathrm{rT}_{3}$ as substrate revealed marked differences in the ability of rat and feline IDI to metabolise this substrate. The rate at which feline liver homogenates metabolised $\mathrm{rT}_{3}$ under the standard assay conditions using $6 \mathrm{nM} \mathrm{rT}_{3}$ was approximately $0 \cdot 2 \%$ of the reaction rate found in rat homogenate. Similar differences in the reaction rate between the rat and the cat were also demonstrated when washed microsomes were used (data not shown), suggesting that there was no inhibitory component in the cytosolic fraction of the cat.

With $\mathrm{rT}_{3}$ as substrate, it was difficult to determine a precise and accurate estimate of $K_{\mathrm{m}}$ in feline liver. This was because the $K_{\mathrm{m}}$ for this substrate was estimated to be much greater than the greatest concentration of $\mathrm{r}^{\prime} \mathrm{T}_{3}$ that could be obtained in solution. However, at a conservative estimate, the $K_{\mathrm{m}}$ of the feline enzyme was at least 500 -fold greater than that of the enzyme in rat liver.

IDI in humans, dogs, mice, chicks and tilapia have been cloned, illustrating several important features (St Germain \& Galton 1997). Site-directed mutagenesis studies have shown that the selenocysteine residue is critical for the catabolism of thyroid hormones (Berry et al. 1991b), and insertion of this selenocysteine requires the presence of a selenocysteine insertion sequence (SECIS) in the 3' untranslated region of the mRNA (Berry et al. 1991a). In addition to the selenocysteine residue, there are two essential histidines at amino acid residues 158 and 174 in rats and humans (Berry 1992) and the phenylalanine at residue 65 of the human IDI is of critical importance in the ability of the enzyme to catalyse the $5^{\prime}$-deiodination of $\mathrm{r}_{3}$ and di-iodothyronine $\left(\mathrm{T}_{2}\right)$ sulphate (Toyoda et al. 1997). The expression of this phenylalanine at residue 65 is highly conserved, except in the dog, in which a leucine is substituted. This substitution at amino acid 65 makes canine IDI very inefficient in catalysing 5 '-deiodination of $\mathrm{rT}_{3}$ and $\mathrm{T}_{2}$ sulphate (St Germain \& Galton 1997). Our observation that cat IDI was even less efficient than the dog at deiodinating $\mathrm{r}^{\prime} \mathrm{T}_{3}$ suggests that, in the cat, similar changes in amino acid sequence may be occurring. However, the fact that the ${ }^{125}$ I-bromoacetyl derivative of $\mathrm{rT}_{3}$ was able to bind to the feline enzyme suggests that any such changes in the amino acid sequence in the feline IDI have a greater effect on the ability of IDI to deiodinate $\mathrm{rT}_{3}$ as compared with the ability of the enzyme to bind $\mathrm{rT}_{3}$. The IDI of tilapia is relatively resistant to inhibition by PTU and GTG, although the structural characteristics responsible for this difference are unknown ( $\mathrm{St}$ Germain \& Galton 1997). However, we have found that IDI in the cat can be inhibited by PTU and GTG, as has been found in other mammals.

Our data suggest that, in the cat as in the rat, a major source of circulating $\mathrm{T}_{3}$ is likely to arise from hepatic deiodination of $\mathrm{T}_{4}$. Indeed, the mean \pm S.D. concentrations of serum $\mathrm{T}_{3}$ in the rat $(1.5 \pm$ $0.14 \mathrm{nM}$; Beckett et al. 1987) and the cat $(0.69 \pm$ $0 \cdot 29 \mathrm{nM}$; Thoday et al. 1984) are similar. Our data further suggest that hepatic metabolism of $\mathrm{rT}_{3}$ 
by IDI cannot proceed at a significant rate in the cat. However, as the serum concentrations of $\mathrm{rT}_{3}$ were significantly lower in the cat than in the rat, this suggests either that the major fraction of serum $\mathrm{rT}_{3}$ does not arise from the liver in the cat or, alternatively, that metabolism of $\mathrm{rT}_{3}$ must occur by alternative pathways. A clear candidate for such a pathway is prior sulphation, with subsequent deiodination of sulphated $\mathrm{rT}_{3}$ (Rutgers et al. 1991).

In rats and humans, sulphation of thyroid hormones is considered to be an important regulator of thyroid hormone metabolism. In these species, some sulphated iodothyronines are deiodinated at a faster rate by IDI than the corresponding nonsulphated iodothyronines (Rutgers et al. 1991). This has led to the suggestion that a balance between the expression of the sulphotransferases, sulphatases and deiodinases involved in thyroid hormone metabolism may be important in the regulation of thyroid hormone expression during foetal development (Richard et al. 1998). We have not been able to examine the ability of feline IDI to metabolise $\mathrm{rT}_{3}$ sulphate or the ability of feline liver to synthesise $\mathrm{rT}_{3}$ sulphate, but clearly this would be of interest. Another possibility is that $\mathrm{r}^{\prime} \mathrm{T}_{3}$ is metabolised in the cat by pathways that do not involve deiodination. Such pathways may involve metabolism of the side chain, ether-bond cleavage, glucuronidation (slow in the cat) or methylation (Beckett \& Arthur 1994). Further studies are required to clarify these issues.

Using affinity labelling and activity assays, we have shown that IDI is not expressed in the thyroid of the cat. In this regard, the cat is similar to goat, cattle, sheep, rabbits, pigs, llama and deer. In contrast, thyroidal IDI is strongly expressed in humans, dogs, rats, mice and guinea pigs and, in these species, expression of the enzyme appears to be regulated through activation of the cAMP cascade, through changes in adenylate cyclase activity (Tang et al. 1994). When thyroidal IDI is expressed, it appears to provide a significant source of circulating $\mathrm{T}_{3}$, particularly when activation of the thyroid-stimulating hormone (TSH) receptor is initiated, such as occurs in hypothyroidism via TSH or in Graves' disease through thyroid-stimulating immunoglobulins. Clearly, therefore, in the cat, thyroidal deiodination cannot be involved in an adaptive response to hypothyroidism. Spontaneous adult-onset hypothyroidism in the cat is extremely rare (Rand et al. 1993). Similarly, thyroidal deiodination of $\mathrm{T}_{4}$ cannot be a source of $\mathrm{T}_{3}$ in the hyperthyroid cat, as we have shown that, in such animals, IDI is not expressed in the thyroid. In these hyperthyroid cats, the increased serum $\mathrm{T}_{3}$

www.endocrinology.org concentrations must arise from peripheral conversion of $\mathrm{T}_{4}$ by IDI, and also possibly through increased de novo synthesis of $\mathrm{T}_{3}$ on thyroglobulin in the thyroid.

In conclusion, our data suggest that, in the cat, plasma $\mathrm{T}_{3}$ originates largely from the deiodination of $\mathrm{T}_{4}$ in the liver and kidney, but clearance of $\mathrm{rT}_{3}$ must proceed by a metabolic route that is not dependent on deiodination of the unsulphated molecule.

\section{ACKNOWLEDGEMENTS}

The authors would like to thank the staff of the Department of Radiology of The Royal Infirmary of Edinburgh for developing the radiographic films and John Arthur and Fergus Nicol of the Rowett Research Institute Aberdeen for advice regarding IDI affinity labelling. This work and the primary investigator (D J F) were supported by a grant from the Pet Plan Charitable Trust.

\section{REFERENCES}

Beckett GJ \& Arthur JR 1994 The iodothyronine deiodinases and 5'-deiodination. In Baillière's Clinical Endocrinology and Metabolism - Hormones, Enzymes and Receptors, pp 285-304. Eds MC Sheppard \& PM Stewart. London: Baillière Tindall.

Beckett GJ, Beddows SE, Morrice PC, Nicol F \& Arthur JR 1987 Inhibition of hepatic deiodination of thyroxine is caused by selenium deficiency in rats. Biochemical Fournal 248 443-447.

Beckett GJ, Beech S, Nicol F, Walker SW \& Arthur JR 1993 Species differences in thyroidal iodothyronine deiodinase expression and the effect of selenium deficiency on its activity. Fournal of Trace Elements and Electrolytes In Health and Disease 7 123-124.

Beech SG, Walker SW, Dorrance AM, Arthur JR, Nicol F, Lee D \& Beckett GJ 1993 The role of thyroidal type-I iodothyronine deiodinase in tri-iodothyronine production by human and sheep thyrocytes in primary culture. Fournal of Endocrinology 136 361-370.

Berry MJ 1992 Identification of essential histidine residues in rat type I iodothyronine deiodinase. Fournal of Biological Chemistry 267 18055-18059.

Berry MJ, Banu L, Chen Y, Mandel SJ, Kieffer, JD, Harney JW \& Larsen PR $1991 a$ Recognition of UGA as a selenocysteine codon in type I deiodinase requires sequences in the 3' untranslated region. Nature 353 273-276.

Berry MJ, Kieffer JD, Harney JW \& Larsen PR $1991 b$ Selenocysteine confers the biochemical properties characteristic of the type I iodothyronine deiodinase. Fournal of Biological Chemistry 266 14155-14158.

Bradford MM 1976 A rapid and sensitive method for the quantitation of microgram quantities of protein utilising the principle of protein-dye binding. Annals of Biochemistry 72 248-254.

Kohrle J 1994 Thyroid hormone deiodination in target tissues a regulatory role for the trace element selenium?

Experimental and Clinical Endocrinology 102 63-89. 
Kohrle J, Rasmussen UB, Ekenbarger DM, Alex S, Rokos H, Hesch RD \& Leonard JL 1990 Affinity labelling of rat liver and kidney type I 5'-deiodinase. Fournal of Biological Chemistry 265 6155-6163.

Leonard JL \& Rosenberg IN 1978 Thyroxine 5'-deiodinase activity of rat kidney: observations on activation by thiols and inhibition by propylthiouracil. Endocrinology 103 $2137-2144$

Leonard JL \& Kohrle J 1996 Intracellular pathways of iodothyronine metabolism. In Werner and Ingbar's The Thyroid, edn 7, pp 125-110. Eds LE Braverman \& RD Utiger. Philadelphia: Lippincott-Raven.

Mitchell JH, Nicol F, Beckett GJ \& Arthur JR 1998 Selenoprotein expression and brain development in preweanling selenium- and iodine-deficient rats. Fournal of Molecular Endocrinology 20 203-210.

Moreno M, Berry MJ, Horst C, Thoma R, Goglia F, Harney JW, Larsen PR \& Visser TJ 1994 Activation and inactivation of thyroid hormone by type I iodothyronine deiodinase. FEBS Letters 344 143-146.

Rand J, Levine J, Best SJ \& Parker W 1993 Spontaneous adult-onset hypothyroidism in a cat. Fournal of Veterinary Internal Medicine 7 272-276.

Richard K, Hume R, Kaptein E, Sanders JP, VanToor H, DeHerder WW, DenHollander JC, Krenning EP \& Visser TJ 1998 Ontogeny of iodothyronine deiodinases in human liver. Journal of Clinical Endocrinology and Metabolism 83 2868-2874.

Rutgers M, Heusdens FA \& Visser TJ 1991 Deiodination of iodothyronine sulfamates by type I iodothyronine deiodinase of rat liver. Endocrinology 129 1375-1381.

Santini F, Chopra IJ, Hurd RE \& Chua Teco GN 1992 A study of the characteristics of hepatic iodothyronine $5^{\prime}$-monodeiodinase in various vertebrate species. Endocrinology 131 830-834.

Sawada K, Hummel BCW \& Walfish PG 1986 Properties of cytosolic components activating rat hepatic 5-deiodination in the presence of NADPH. Biochemical Fournal 234 391-398.
Schoenmakers CHH, Pigmans IGAJ \& Visser TJ 1992 Species differences in liver type I iodothyronine deiodinase. Biochimica et Biophysica Acta 1121 160-166.

Silva JE \& Larsen PR 1986 Regulation of thyroid hormone expression at the prereceptor and receptor levels. In Thyroid Hormone Metabolism, pp 441-500. Ed G Hennemann. New York: Marcel Decker.

St Germain DL 1994 Iodothyronine deiodinases. Trends in Endocrinology and Metabolism 5 36-42.

St Germain DL \& Croteau W 1989 Ligand-induced inactivation of the I iodothyronine $5^{\prime}$-deiodianse: protection by propylthiouracil in vivo and reversibility in vitro. Endocrinology 125 2735-2744.

St Germain DL \& Galton VA 1997 Review: the deiodinase family of selenoenzymes. Thyroid 7 655-668.

Tang K-T, Braverman LE \& DeVito WJ 1994 Effects of fibroblast growth factor on type I 5 -deiodinase in FRTL-5 rat thyroid cells. Endocrinology 135 493-500.

Thoday KL \& Mooney CT 1992 Historical, clinical and laboratory features of 126 hyperthyroid cats. Veterinary Record 131 257-264.

Thoday KL, Seth J \& Elton RA 1984 Radioimmunoassay of serum total thyroxine and triiodothyronine in healthy cats: assay methodology and effects of age, sex, breed, heredity and environment. Fournal of Small Animal Practice $\mathbf{2 5}$ $457-472$.

Toyoda N, Kaptein E, Berry MJ, Harney JW, Larsen PR \& Visser TJ 1997 Structure-activity relationships for thyroid hormone deiodination by mammalian type I iodothyronine deiodinases. Endocrinology 138 213-219.

Visser TJ \& Overmeeren-Kaptein E 1981 Substrate requirement for inactivation of iodothyronine- 5 '-deiodinase activity by thiouracil. Biochimica et Biophysica Acta 358 202-208.

Visser TJ, Kaptein E, Terpstra T \& Krenning EP 1988 Deiodination of thyroid hormone by human liver. Fournal of Clinical Endocrinology and Metabolism 67 17-24.

REVISED MANUSCRIPT RECEIVED 20 August 1999 